University for Business and Technology in Kosovo

UBT Knowledge Center

Nov 2nd, 9:00 AM - Nov 3rd, 5:00 PM

\title{
Impact of Civil Servant Salaries on the Performance of Local Public Administration in Kosovo
}

\author{
Naim Ismajli \\ European University of Tirana \\ Emira Qosja \\ European University of Tirana
}

Follow this and additional works at: https://knowledgecenter.ubt-uni.net/conference

Part of the Business Commons

\section{Recommended Citation}

Ismajli, Naim and Qosja, Emira, "Impact of Civil Servant Salaries on the Performance of Local Public Administration in Kosovo" (2012). UBT International Conference. 36.

https://knowledgecenter.ubt-uni.net/conference/2012/all-events/36

This Event is brought to you for free and open access by the Publication and Journals at UBT Knowledge Center. It has been accepted for inclusion in UBT International Conference by an authorized administrator of UBT Knowledge Center. For more information, please contact knowledge.center@ubt-uni.net. 


\title{
Impact of Civil Servant Salaries on the Performance of Local Public Administration in Kosovo
}

Phd. Cand. Naim Ismajli [1], Dr. ErmiraQosja [1]

[1] European University of Tirana, Albania

\begin{abstract}
Motivation is defined as the willingness to exert high level of effort to reach organizational goals, conditioned by the ability of these efforts to satisfy some individual needs (Robbis / De Cenze p, 407). As motivating factors are: wage increase in career, workplace safety, work contracts, working conditions, organizational culture, leadership in working organizations, the level of responsibility at work and rewards. All these factors have different scale in motivating employee performance. Based on the theory of many authors in the field of Human Resources, presented in scientific literature, scientific journal articles, reports of international institutions (UNDP, World Bank, Human rights etc.)that explore human resources comes the conclusion that the salary is one of the most important motivating factors for employee performance level.

Main problem treated in this research is the salary; salary level, its structure, the methodology of determining the current legal framework does not provide a realistic reflection based on needs and performance-oriented employees, so as it is does not motivates either increase public service quality.This work reflects over presented theoretical part from literature, scientific articles, as well from own experience and the main conclusion is that wage is motivating factors in the performance of civil servants in the public administration in local level.

Research questions are; which is unsatisfactory levelwithin worker's salary?, What is the salary structure?, What is actual legal framework?, Is it wage rate based on performance or work time?

For this research will be used combined methodology; first collection of the primary, secondary data, and interviews, with the objective to draw scientific conclusions of this research.

The purpose of this research is to come out with recommendations for institutions to develop policies, local government, human resource managers, executives managers at all levels, but also for its employees to develop policies, to build structures and apply procedures who will enable management technology to increase the salary management system as a key influential factors for high performance level within public sector in Kosovo.
\end{abstract}

Keywords:public administration, salaries, performance measurement, public servants, local governance, Kosovo,

\section{INTRODUCTION}

Efficient and professional Public administration, prepared to respond to citizens' demands is the common aspiration of all the institutions of the Republic of Kosovo. To achieve this goal, of special importance is the establishment of standards that contribute not merely to increase the effectiveness and quality of operations but also, more generally, the quality of workin g life of employees in the state administration. Establishment of such standards for the management of human resources is particularly important not only because it presents powerful device for measuring the fulfillment of the employed, but they are also the b as is for upgrading and further development of human resources, which possess the institution.

The implementation of these standards by the institutions and by other public sector organizations, will contribute not only in terms of improving the work of the institution but also generally in the professional development of the employees. Howe ver, their implementation will strengthen the role of human resource units, which represents an important step to professional pub lic service as best way towards European integration processes.

Performance management is essentially an incentive system for employees and their superiors, but at the same time provides a check on all hierarchical levels, if applied well and found the support of the leaders of the institution.

Through proper motivation, usually is aimed to achieve increase of performance and sat isfaction of employees thatkeeps up "morality" under the civil servants. Different techniques for staff performance management, aimed at identifying gaps and eliminating weaknesses with focus on performance increase. This as well intended to maintain high level of motivation of staff and their focus on the objectives of the institution. Human resources, or simply people involved in the production and distribution of products - whether goods or services, are one of the most important resources in all organizations / institutions. 
Human resources include all members of an organization / institution starting from the top managers to the lowest levels of the institution. In this sense, they are effective leaders, who understand how important and valuable human resources are and take concrete steps to ensure that their organization supports and fully utilizes its human resources, ensuring in this way a great advantage in competition with others.

Contemporary theories about the management and the nature of organizational effectiveness provide a positive treatment of such important resources and it gives to the people courage to work with desire and achieve best possible results. However is diff icult to achieve in practice what usually is described and aimed in advance or in the theory.

Many executives tend to run more through rules, procedures and paperwork than with and through people. It is important that they have a highly developed sense of human perception, to understand the feelings of the staff, their needs and what they expect. In first line you have to understand that here are people to be managed, so they should be treated in human terms. Sincere concern for people and their welfare is most valuable aproach of encouraging them to achieve good results.

Based on the theories of many authors in the field of human resources [HT Graham \& Roger Bennett: Human Resources management, Great Britain, 1998; Paul Banfield - Rebecca Kay: An Introduction to Human Resource Management; Robbins / Decenzo: Fundamentals of Management-translation UET Tirana 2011; F. Bahtijarovic: MenagementLjudskih potenciala, Zagreb 1999, presented in scientific literature; scientific papers, scientific journal articles, reports of international institutions (UNDP, World Bank, Human rights etc.]that explore human resources comes out the conclusion that salary is one of the most important motivating factors for the level of performance of employees within Institution.

Motivation is defined as the willingness to exert high levels of effort to reach organizational goals, conditioned by the ability of these efforts to satisfy some individual needs (Robbis / De Cenze p, 407), as motivating factors are: salary, advancement in career, workplace safety, work contracts, working conditions, organizational culture, leadership in working organizations, the level of responsibility at work (degrees), bonuses etc.

All these factors have different scale of reflections on the motivation andperformanceof employees. Any of those depends on the reasons that attract people or their needs.

According to Maslow, there are general types of needs (physiological, safety, love, esteem) that must be satisfied before a person can act unselfishly. He called these needs "deficiency needs." As long as we are motivated to satisfy these cravings, we are moving toward growth, toward self-actualization. Satisfying needs is healthy, blocking gratification makes us sick or evil. In other words, we are all "needs junkies" with cravings that must be satisfied and should be satisfied. Else, we become sick.

Needs are prepotent. A prepotent need is one that has the greatest influence over our actions. Everyone has a prepotent need, but that need will vary among individuals. A teenager may have a need to feel that he/she is accepted by a group. A heroin addict will need to satisfy his/her cravings for heroin to function normally in society, and will not worry about acceptance by othe $\mathrm{r}$ people. According to Maslow, when the deficiency needs are not met: At once other (and higher) needs emerge, and these, rather than physiological hungers, dominate the organism. And when these in turn are satisfied, again new (and still higher) needs emerge, and so on. As one desire is satisfied, another pops up to take its place.

\section{Physiological Needs}

Physiological needs are the very basic needs such as air, water, food, sleep, sex, etc. When these are not satisfied, we may feel sickness, irritation, pain, discomfort, etc. These feelings motivate us to alleviate them as soon as possible to establish homeostasis. Once they are alleviated, we may think about other things.

\section{Safety Needs}

Safety needs have to do with establishing stability and consistency in a chaotic world. These needs are mostly psychological in nature. We need the security of a home and family. However, if a family is dysfunction, i.e., an abusive husband, the wife cannot move to the next level because she is constantly concerned for her safety. Love and belongingness have to wait until she is $\mathrm{n} o$ longer cringing in fear. Many in our society cry out for law and order because they do not feel safe enough to go for a walk in their neighborhood. Many people, particularly those in inner cities, unfortunately, are stuck at this level. In addition, saf ety needs sometimes motivate people to be religious. Religions comfort us with the promise of a safe secure place after we die and leave the insecurity of this world.

\section{Love and belongingness Needs}

Love and belongingness are next on the ladder. Humans have a desire to belong to groups: clubs, work groups, religious groups, family, gangs, etc. We need to feel loved (non-s exual) by others, to be accepted by others. Performers appreciate applause. We need to be needed. Beer commercials, in addition to playing on sex, also often show how beer makes for camaraderie. When was that last time you saw a beer commercial with someone drinking beer alone?

\section{Esteem Needs}

There are two types of esteem needs. First is self-esteem which results from competence or mastery of a task. Second, there's the attention and recognition that comes from others. This is similar to the belongingness level, however, wanting admiration has to do with the need for power. People who have all of their lower needs satisfied, often drive very expensive cars because doing so rais es their level of esteem. "Hey, look what I can afford!"

\section{Self-Actualization}

The need for self-actualization is the "desire to become more and more what one is, to become everything that one is capable of becoming." People who have everything can maximize their potential. They can seek knowledge, peace, esthetic experiences, 
self-fulfillment, oneness with God, etc. It is usually middle-class to upper-class students who take up environmental causes, join the Peace Corps, go off to a monastery, etc.

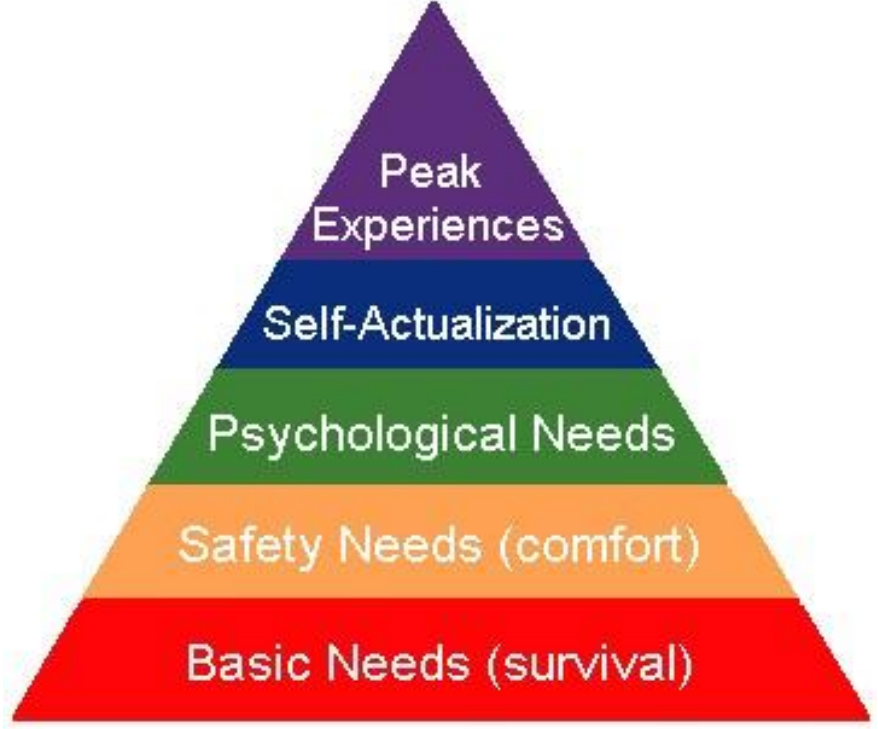

Figure 1. Abraham Maslow, Motivation and Personality, 2nd ed., Harper \& Row, 1970.

This research focuses on salary as motivational factors in the performance of civil servants in public local administration. A big commitment and a challenge to organizations and institutions is setting the wage level which will be paidto the employees in the organization. The high fee, characterized by budget deficit causes problems in financial sustainability in the organization, as well as lower payments does not causes satisfaction by employees and demotivate civil servants to work better. As final result we will have lower performance level in organizations and institutions.

Payment rates to be selected for employee salary depend on two factors category; external factors and internal factors.

Internal factors can be noted; volume of work, nature of work, expertise required the level of accountability, the level of safety in the workplace, the organization's ability to pay.

While external factors be determined as the level of unemployment in the country and the region, and the requirements for consumer basket consumption.If the consumptionbasket has high cost and the unemployment rate is greater than wage level should be increased constantly and this should be e negotiated with worker unions.

Most payment systems in organizations or public institutions where the employee is given a fixed monthly salary which is based on fixed timetable. Differences in capacity and competence are also to explain the different levels of salary. Performance ba sed payments are the best way to motivate the establishment of individual performance with the performance of organization.Payment based on performance should be based on the objectives set as benchmarks (evaluation) and depending on the level of achievement made.

This methodology of payment requires setting standards with clear and measurable targets in quality and quantity, as well preparation for their assessment expert.

Performance-based salary is one of the most advanced ways to motivate workers for this kind of payment should be set in advance performance metrics (P.Bondia and G.Blau, , International Journal of Human ResourceManagement, in February 1971, f.271-288)

Hourly wage rate or job level and performance value is a challenge that will not answer to the salary as motivational factors (ROBBINS / DeCENZO). Other motivation is possibility to work from home and her very large application brings question marks for salary comparing to the hours., Work flexible hours is also are an important factor with salary structure s tudy.

\section{THE POURPOSE OF THE RESEARCH-WAGES AS MOTIVATIONAL FACTORS FOR THE EMPLOYEE PERFORMANCE INCREASE}

A big commitment and a challenge to organizations and institutions is setting the wage level which has to be paid the employe es in the organization, high fee, characterized by budget deficit causes problems in financial sustainability in the organization.

Wages refers to "the total emolument paid to a worker for performing services..." In other words, wage is the payment made to labor for his contribution to the attainment of the goals of an organization (Eniaiyejuni, 2005).

Eniayejuni (2005) listed three dimensions of wages as follows:

(i) Money Wage: The amount of money received by the employee at the end of the working period or the amount receiv ed per unit of output.

(ii) Real Wage: The quantity of goods or services the money can buy. 
(iii) Average Wage: This takes into consideration the total wage bill and how it translates to hourly or daily rate for each employer.

Acording to this point of view determinants of Wages and Salaries are as follows:

(a) The Labour Market Situation: The wages and salaries payable is premised on market forces, that is, the demand and supp ly situation.

(b) The Prevailing Wage Rate: The going rate in a particular labour market or industry.

Those problems are almost everywhere reflected in transition countries and therefore this has pushed me toward this research that includes many key point. To verify that the salary is motivating factor in the performance of civil servants in the public administration, investigate satisfactory levelof worker'swith their wage, salary structure, legal framework and procedure for determining the salary of civil servants in local public adminis tration. For this research I used co mbined methods; first collecting source data, primary and secondary, and parallel to this interviews, with the objective to draw scientific conclusions of th is research.

The purpose of this research is to is sue recommendations for institutions to develop policies, local government, human resources managers, executives managers at all levels, but also for its employees to develop policies, to build systems and procedures apply who dote enabling technology management as perfect my salary management system as key factors, with clear target for the highest level of performance of public administration employees (Case Study Local Government in republic of Kosovo).

Social and economic development of a country plays an important role in welfare which aims to fill out the social and economic needs, health and regenerative members of the society. Wages as a concept represents compensation or income able to express them in front of certain laws or mutual agreement for a business process or service.

It should express a lot of benefits in exchange for the contribution to the employee and therefore organizations should be complementary. There exist many global organizations that care about the payment calsulation and the manner of its applicatio $n$ by the employers, in order for it to express the value of the work.

In this regard, two prominent economists Mare J.Wallaceand Charles H.Fay have evidenced the fact that "Justice is achieved when it is given in return equivalent investment made" (Compensation Theory and Practice, 2d; Bonston PWS-Kent, 1988). Basis for determining the salary premium is "equal pay for equal work for equal work."

Salary is the main motivating factor for employees. Determination of such compensation should be based on competition in the labor market, financial sustainability potential and be competitive to attract new employees. Performance evaluation is a process or technique where the relative value or the validity of a job can be determined in a systematic and transparent way, even if additional requirements for objectivity.

\section{EMPLOYEE MOTIVATION FROM MANAGERS}

We typically assume that people are primarily motivated byexternal factors (extrinsic motivation). In other words, people will work better or be more committed if they receive significant material gains, such as a large paycheque or more holiday time.

Research has shown, however, that many of our assumptions about economic-based motivation are untrue. In fact, employees are often more motivated as a result of internal factors (intrinsic motivation). Employees' pride in workmanship or their ability to help customers is often much more of a motivating factor than money or self-interest.

Despite this fact, it is important to note that extrinsic and intrinsic rewards complement each other, and that one is not sufficient without the other. Each becomes an issue when it is insufficient or unfair. For example, pay will become more important whe $n$ employees are short of money or when unfairness is perceived. Intrinsic rewards are what keep employe es motivated while they perform their daily tasks and duties.

Everyone is different when it comes to motivation. While some people are motivated by the potential to earn rewards, others are motivated primarily by their desire to avoid unpleasant consequences. It takes time and good listening skills to determine how to best motivate each employee.

There is no doubt that figuring out how to motivate employees remains a complex and challenging dilemma. The following tips on motivation I think may be helpful:

No one can cause anyone to do anything; the motivation comes from within.

We can create circumstances in which people motivate themselves.

You've got to walk the talk.

If you listen long enough, people will tell you what motivates them.

Some people are motivated more by rewards and some people are motivated more by (fear of) consequences.

If you watch long enough, people will show you how to motivate them.

You can waste a lot of time giving rewards to people who aren't motivated by them.

The Managerial Golden Rule: "Do unto others as they would like to be done unto!"

Currently the level of wages in public Institutions is not acceptable because when comparing the needs and consumer basket with salaryis a great disproportion.

Once monthly salary does not cover the monthly family costs. The optional solution is that people try to find the secondary solution that might affect the work performance, so this phenomenon impacts de-motivating employees and lose the will to have the maximum commitment in the organization where they works.

Based on the law on salaries of civil servants of the Republic of Kosovo Nr.03/L-149 is extracted; Regulation on the classification of jobs in the service servants Nr.05/2012. 
According to this regulation as criteria for job classification and salary grade are: responsibility at work, the complexity of the task at work, interpersonal communication skills, qualification, and professional experience.

With this regulation are certain levels as functional categories, with coefficient salary grades, as well as progressive steps to increase the salary.

Determine four levels as functional category: senior management level, management level, professional level and administrative level.

$\square$ senior management level represents important functions in determining the strategic objectives of the institution, requires high organizational skills, communication, experience and preparation senior management consists of three degrees; each grade by five steps.

$\square$ Managing directors present level positions of leadership level to sector level. This leader characterized by these specificities; responsibility for decision-making, policy-making, allocation within the institution's objectives, professional assessment of the policies and performance of workers, the ability to work motivational team communication, supervision, control, etc..; consists of four degrees and twelve steps.

$\square$ presents professional level professional positions in the institution which include assistance in the development of policies, their implementation and professional services (engineer, accountant, information technology, etc.). Consists of three degree s and twelve steps

$\square$ administrative level includes administrative and technical functions in relevant areas of civil service, consists of four degrees and twelve steps.

\section{WORK METHODOLOGY}

This research is based on data collection and usage of information from different theoretical resource books, scientific pape rs that addresses areas of special emphasis on human resources; performance, in particular the salary motivation as the main motivational impact factor on the employee performance. During this research I have used other sources relevant to this paper, such as laws and other normative acts including: Law on local self government, Nr.2008/03-L040 dated 15.6.2008;Law on Civil Service of the Republic of Kosovo Nr.03/L-149 dated 14.62010; Law on Salaries of Civil Servants of the Republic of Kosovo Nr.03/L-147 dated 14.6.2010, the Labor Law Nr.03/L-212 dated 1.11.2010

Secondary legislation; Regulation on standards of internal organization and systematization of jobs in the state administration Nr.09/2012,

Rules for the classification of jobs in the service servants Nr.05/2012,

Regulation on the job description Nr.03/2010 that regulate this area, official reports from the institutions: Statistical Office; Report 2011, UNDP; Report 2011, World Bank; report in 2011, provided for salary and its level.

One other primary source of information and data were interviews with civil servants in local public administration.

The interview was structured mainly from basic questions with the possibility of sub-questions. There were 10 basic questions;

1. Which salary level you have?

2. How much are you satisfied with this level the salary?

3. How familiar are you about the law on the new wage for civil servants?

4. Job classification according to the rules you think will have have positive impacts in your salary?

5.Are you satisfied with the job?

6. Have you been advanced in career and evaluate the advancement process?

7. Have you had assessment of performance and what do you think about it?

8. What are prohibitions applied to work and how?

9. Are you paid for overtime hours (royalty) and do you like this practice?

10. What motivates you more in your work?

In total there were interviewed 32 administration officials within local government level. The structure of hierarchic position of the respondents was:

8 respondents were senior managers

8 respondents were managers,

8 respondents were professional level employees, and

8 respondents were from the administrative level. 


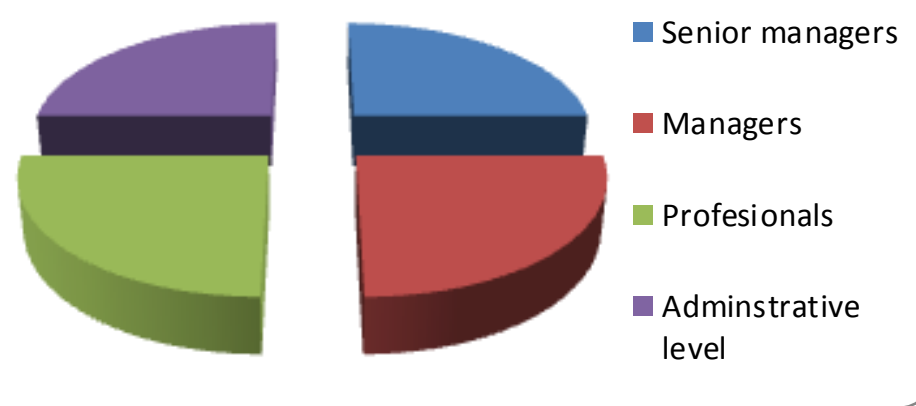

Figure 2. Structure of respondent's interviewed during research

After processing the data from the interviews following results were in the place:

Lowest salary of the respondents was 216 Euros (gross), highest salary from respondents was 930 Euro (gross), while the average of the respondents was 345 Euros (gross)

With the salary level to some degree are satisfied employees of the senior management level and management level while professional level employees and administrative are dissatisfied.

About the knowledge for the new wage law and regulation of job classification and salary grades, only $10 \%$ of respondents were aware and almost $80 \%$ of them expressed skeptical opinion about positive changes.

$\square$ In their statement to their work place conditions two highest managerial levels in $70 \%$ of cases they appreciated their work, and for other two levels only $40 \%$ of them considered those conditions acceptable.

Regarding the statement what motivates them mostly to bring and increase performance in their work, in general salary was mention as most appropriate measure for motivation. However high managerial levels they do consider that rewards and advancement in career are important factors motivating them through their work.

\section{RESULT DISCUSION}

$\square$ based on the theory derived from the literature; books, scientific works, magazines, thesis that salary as motivational factors have a direct impact on the establishment and development of performance seems to be indeed realistic.

$\checkmark$ A greater commitment and a challenge to organizations and institutions is setting the wage level which allows space for correct pay of employees in the organization. This has positive impact within institution as well on the advancement, stability and performance increase.

$\square$ This conclusion that derives from the literature and theories presented in books and scientific papers, as well as the results of our research with interviews with employees fully supports the idea that better salaries impact higher performance by employees.

$\square$ Under the applicable legal framework and its applicability wage levels, wage system and its structure are not satisfying civil servants in the public administration in local level.

Thereof is usual that if people are not satisfied with their wages, they lack motivation and this mostly expressed to professional and administrative levels of employees and a bit less concerns high level managers in local government administration.

Low wage incentives as motivational factors have significant impact on the performance of civil servants in local public administration.

$\square$ The lack of motivation has negative impacts not just for low performance in the sector but also this increase the opportunity for corruption under public sector servants.

Finally numerous and frequent departures of experts and professionals from the public administration are leaving the sector and requesting better financial support in private sector. This makes difficulties to build professional and independent public service in local and central level while is difficult to have continuity.

\section{RECOMANDATIONS}

While it is true that money isn't everything when it comes to employee satisfaction, fair and equitable remuneration practices are essential to positive employee relations and employee retention. If you want your paycheques to reflect employee performance, make sure that you have outlined clear expectations and goals for employees.

You can also compensate your employees through non-monetary means. These rewards can range from formal benefits (such as health and dental insurance) to more informal perks (such as flex time or sick child leave). First and foremost, rewards must be meaningful to each employee. Because everyone is unique, you might have to tailor rewards depending on pers onal preferences. Therefore according to the findings of this paper below are recommendations' in order to improve overall situation in the loc al administration

$\square$ Change and amendment of the Law on Salaries of Civil Servants where local officials should be involved in discussions and debates while they know better the problems in the field.

$\square$ Prepare and issue guidelines and other legal acts that enable the implementation of the new amended law on civil servants salaries.

$\square$ To develop training modules for managers. Managing human resources and other managers for the implementation of the Law on salaries for civil servants is crucial for improvement of the situation 
To increase the level of existing minimal and lower salaries to the level where the average salary covers the cost of monthly expenditure, by analyzing all the influencing factors.

Analyzing the level of grades and salaries analyzed compared to the scope of work and level of performance.

To apply for alternative employment; part-time, distance work, purchase services from specialized companies, depending on the need for the services and works.

$\square$ During the drafting of the budget being devoted to carefully separate quota for raising wages in relation to other categories of expenditures while respecting the criteria of the IMF (International Monetary Fund) as one of institutions that helps Kosovo in regard of financial stability that is very important for overall stability of the country.

\section{CONCLUSION}

Your remuneration strategy is an important ingredient in your overall human resource strategy. A good compensation plan can increase employee satisfaction and motivation, resulting in increased production and employee retention rates. This can have a spin-off effect, resulting in positive public relations and customer satisfaction.

Although an employee's paycheque is a component of most compensation plans, it is worth noting that compensation is not onlymeasured monetarily. A mix of benefits and perks can also be used to remunerate your employees. By linking rewards to employee performance, you can increase employee motivation and achieve winning results.

\section{References}

1. Strategic human Resource Management Second edition 2; Jeffrey A.Mello, Towson University

2. Hyrje në menaxhimin e burimeve njerëzore; Paul Banfield.Rebecca Kay (përkthim ;Jonida Bregu

3. Human Resource Management Ethics and Employment edited by; Ashly Pinnington,Rob Mocklin and Tom Campbell.

4. A Handbook of Human Resource Managemente Practice; Michael Armstrong

5. Menaxhimi i Burimeve Njerëzore; Dr Galantina Canco (Doracak),(f. 182-222)

6. Human Resource Management; Derek Torrington, Laura Hall, Stephen Taylor

7. Menaxhimi i Resurseve Humane ; Dr Enver Kutllovci (f.71-76)

8. ARTHUR J. B. (1994), Effects of human resource systems on manufacturing performance and turnover, Academy of Management Journal, VOL. 37, Nr. 3.

9. LAURSEN K., FOSS N. J., New human resource management practices complementarities and the impact on innovation performance, Cambridge Journal

10. Standarde për administrim m eresurse njerëzore;Sekretariati për çështje evropiane Agjencioni për nëpunës zyrtarë-Sekretariati gjeneral i Qeverisë së Republikës së Maqedonisë. ISBN 978-9989-182-25-9 